\title{
E-VOTING BERBASIS WEB DAN WAP DALAM PEMILIHAN KEPALA DESA KABUPATEN MUSI RAWAS
}

\author{
Arie Yandi Saputra, Robi Yanto \\ Program Studi Sistem Informasi, STMIK Bina Nusantara Jaya Lubuklinggau \\ J1. Yos Sudarso No.97 A Jawa Kanan Kota Lubuklinggau Sumsel \\ Telp: (0733) 322307 Fax: (0733) 322306 \\ E-mail: arielahat@gmail.com
}

\begin{abstract}
Musi Rawas since 2013 have made use of the e-voting village elections. However, in practice it less effective and efficient because of equipment owned limited, resulting in the many funds expende. The aim of the research is to produce simulation applications of e-voting in the election of village heads and WAP based website. The concept of work of the e-voting system is done online, so that the implementation of the elections will be more effective and efficient because these systems can be used together in the same time. The e-voting system has functional requirements that are able to accommodate the data of voters, voter data validation, the electoral system, and a sound accounting system that meets the criteria of e-voting. Judging from the results of this peneitian shows that application-based online e-voting can beapplied and enough savings for implementation can be done simultaneously by the use of an e-voting application.

\section{Abstrak}

Kabupaten Musi Rawas sejak tahun 2013 telah memanfaatkan perangkat e-voting dalam pemilihan kepala desa. Namun dalam pelaksanaannya dinilai kurang efektif dan efisien karena peralatan yang dimiliki terbatas, sehingga mengakibatkan akan banyaknya dana yang dikeluarkan. Tujuan dari penelitian adalah menghasilkan aplikasi simulasi e-voting pada pemilihan kepala desa berbasis website dan WAP. Konsep kerja dari sistem e-voting ini dilakukan secara online, sehingga pelaksanaan pilkades akan lebih efektif dan efisien karena sistem ini dapat digunakan secara bersama-sama dalam waktu yang bersamaan. Sistem e-voting ini memiliki kebutuhan fungsional yang mampu mengakomodir data calon pemilih, validasi data pemilih, sistem pemilihan, dan sistem perhitungan suara yang memenuhi kriteria evoting. Dilihat dari hasil penelitian ini menunjukan bahwa aplikasi e-voting berbasis online dapat diterapkan dan cukup menghemat biaya karena pelaksanaannya dapat dilakukan secara bersamaan dengan menggunaan satu aplikasi e-voting.
\end{abstract}

Kata kunci: e-voting, wap, website

\section{PENDAHULUAN}

Penerapan E-voting telah dilakukan diberbagai negara dengan berbagai model dan dalam 10 tahun terakhir, adopsi e-voting sebagai suatu sistem demokrasi telah banyak dilakukan, tidak hanya di Amerika tapi juga sejumlah negara lainnya. Model adopsi e-voting pun sangat beragam, misalnya di Belgia dan Belanda, kedua negara ini menggunakan smart cards dan touch screen computer. Menurut Hajjar, et.al (2006) bahwa pertimbangan utama terhadap penerapan e-voting adalah akurasi dan kecepatan. Di Indonesia, Badan Pengkajian dan Penerapan Teknologi (BPPT) sudah memulai melakukan studi kelayakan penerapan teknologi ini di Kabupaten Jembrana, Bali pada tahun 2008 silam, sedangkan untuk di daerah kabupaten Musi Rawas, baru dilakukan pada tahun 2013 kemarin di dua desa, dimana pelaksanaan evoting ini didasarkan pada PERDA Kabupaten Musi Rawas Nomor 4 Tahun 2013. Pelaksanaan pilkades dengan menggunakan e-vote pertama kali di kabupaten musi rawas dilakukan secara serentak di dua desa yaitu, Taba Renah Kecamatan Selangit dan Desa U2 Purwodadi Kecamatan Purwodi. Secara umum pelakasanaan pilkades ini berjalan dengan baik, namun karena jumlah peralatan $e$-voting yang dimiliki terbatas dan jumlah pemilihan kepala desa yang mencapai ratusan di tiap tahunnya maka pelaksanaan pilkades di Musi Rawas tidak dapat dilakukan secara efektif dan efisien. Untuk mengatasi permasalahan tersebut, maka perlu dirancang sebuah sistem e-voting yang dapat mengefektifkan dan mengefisienkan pelaksanaan pilkades di musi rawas. E-voting dengan konsep kerja online dapat dijadikan solusi karena konsep kerja online tidak memiliki batasan baik dari sisi jumlah akses, maupun waktu akses sehingga sistem pilkades ini dapat digunakan secara bersama-sama dalam waktu yang bersamaan. 


\section{METODOLOGI}

Dalam penelitian ini peneliti menggunakan metodologi pengembangan sistem SLC (System Life Cycle). Pemilihan metode ini dikarenakan metode SLC memiliki tahapan-tahapan yang diperlukan dan bersifat terjadwal serta mudah untuk di kontrol. Menurut Mc. Leod dalam Isnaini (2009) System Life Cycle (SLC) terdiri dari beberapa tahap yaitu, tahap perencanaan, analisis sistem, perancangan sistem, implementasi sistem, dan tahap penggunaan dan pengujian.

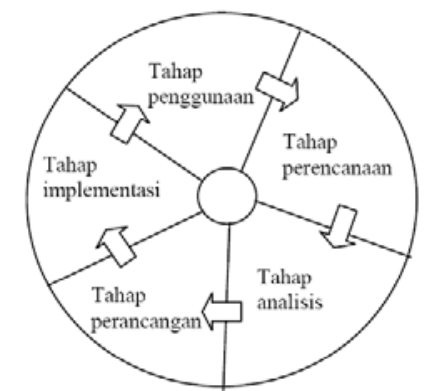

Gambar 1. Metodologi Penelitian Model SLC

Dari gambar 1 terdapat 5 tahapan yang harus dilakukan. Kelima tahapan tersebut adalah:

1. Tahap Perencanaan

Tahap ini merupakan tahap pengumpulan data mengenai sistem pemilihan (voting) dan sistem pemilihan elektronik ( $E$-voting). Data sistem pemilihan elektronik ini diambil dari sistem pemilihan kepala desa yang telah dilakukan sebelumnya. Adapun data yang diambil adalah data calon kepala desa, visi dan misi calon, serta data Daftar Pemilih Tetap dimana nantinya data tersebut akan digunakan sebagai acuan dalam merancang basis data. Selanjutnya adalah pencarian data literatur mengenai sistem pemilihan yang digunakan seperti perda No.4 Tahun 2103 tentang tatacara pelaksanaan pilkades, dan juga literatur lainnya yang berkaitan dengan e-voting.

2. Tahap analisis

Adapun beberapa kegiatan pada tahap analisis, yaitu meliputi identifikasi input ,output, dan skema basis data. Dimana peneliti melakukan analisis terhadap jenis inputan dan keluaran yang dihasilkan seperti penggunaan nomor KTP sebagai identitas pemilih serta analisa terhadap formulir pemilihan kepala desa. Selain identifikasi input dan output, peneliti juga melakukan analisis terhadap proses. Analisis proses merupakan pendefinisian dari skema sistem $e$-voting dalam bentuk fungsi-fungsi yang akan digunakan dalam sistem untuk mengolah masukan sehingga menghasilkan keluaran yang baik sesuai dengan aturan yang berlaku.
3. Tahap Perancangan

Setelah analisis dilakukan, maka hasil analisis tersebut harus dituangkan dalam bentuk perancangan. Dalam tahap perancangan ini, peneliti membagi beberapa jenis perancangan atau desain, yaitu :
a. Desain input
b. Desain output
c. Desain Basis data
d. Desain fungsi atau proses.

4. Tahap Implementasi

Implementasi pada sistem mobile voting ini dilakukan dengan menggunakan bahasa pemrograman PHP, teknologi WAP, dan database MySQL.

5. Tahap Penggunaan dan pengujian sistem Pengujian dilakukan untuk mendeteksi kesalahan serta memastikan setiap input yang dimasukan menghasilkan output yang diharapkan. Dalam pengujian ini peneliti menggunakan metode black box.

\section{HASIL dan PEMBAHASAN}

\subsection{Skema E-Voting}

E-Voting (Electronic voting) adalah proses pemilihan umum yang memungkinkan pemilih untuk mencatatkan pilihannya yang bersifat rahasia secara elektronik yang teramankan (Rokhman, 2011). Menurut Hardjaloka (2001), Terdapat banyak sekali pilihan teknologi yang dapat digunakan dalam pelaksanaan e-voting seperti penggunaan smart card untuk autentifikasi pemilih, penggunaan internet sebagai sistem pemungutan suara, penggunaan touch screen sebagai pengganti kertas suara, dan masih banyak beberapa variasi teknologi yang dapat digunakan. Di Indonesia penggunaan evoting secara bertahap mulai diterapkan. Umumnya, pelaksanaan e-voting masih dilakukan untuk skala kecil seperti pemilihan pimpinan organisasi baik organisasi kemasyarakatan maupun yang bersifat bisnis. Sampai tahun 2011 ini baru satu daerah di Indonesia yang telah menerapkan e-voting dalam proses pemilihan di daerahnya yaitu Kabupaten Jembrana. Hanya saja e-voting yang diterapkan di Jembrana baru sebatas untuk pemilihan Kepala Dusun.

Tujuan dari sistem keamanan e-voting adalah untuk menjamin privasi atau kerahasiaan pemilih serta keakuratan pilihan. Keamanan sistem ini memiliki beberapa kriteria, yaitu:

1. Eligibility, Hanya pemilih yang terdaftar yang dapat melakukan pemilihan.

2. Unreusability, Setiap pemilih hanya dapat memilih satu kali.

3. Anonymity, Pilihan pemilih dirahasiakan.

4. Accuracy, Pilihan tidak bisa diubah dan dihapus selama atau setelah pemilihan dan 
juga tidak bisa ditambahkan setelah pemilihan ditutup.

5. Fairness, Perhitungan suara sebelum pemilihan ditutup tidak bisa dilakukan.

6. Vote and Go, Pemilih hanya dapat melakukan pemilihan saja.

7. Public Verifiability, Semua orang dapat melakukan pengecekan pada berjalannya proses pemilihan. (canard dan sibert, 2001).

\subsection{Arsitektur Sistem}

Untuk menggunakan hak pilihnya, pemilih hanya datang kemudian menukarkan undangan yang telah dibagikan oleh pihak panitia sebelumnya dengan username dan password, lalu pemilih dapat melakukan voting dengan perangkat handphone masing-masing atau dengan fasilitas pendukung yang telah disediakan panitia.

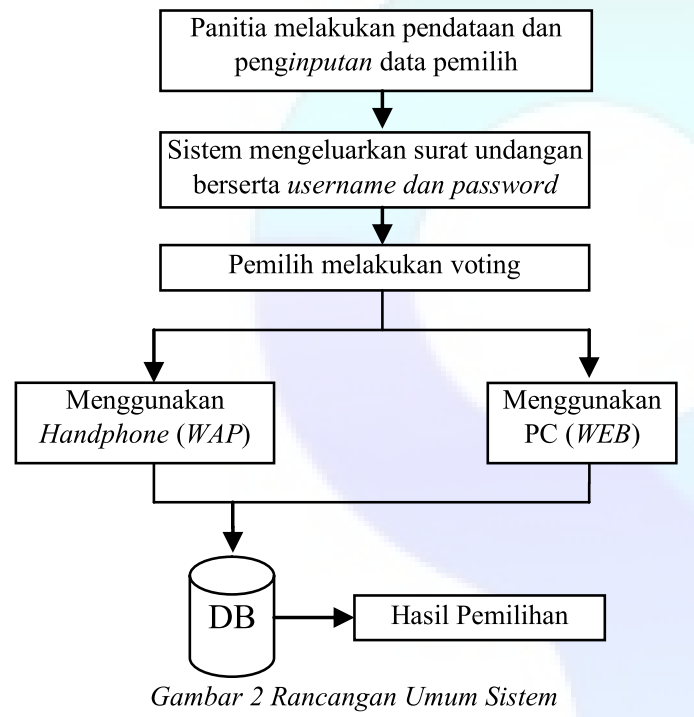

\subsection{Analisis Kebutuhan}

Pada tahap ini dilakukan analisis terhadap kebutuhan sistem dari data dan literatur yang didapat dengan hasil.

1. Hasil analisis skema e-voting

a. Hanya pemilih yang sudah terdaftar dan mendapatkan undangan serta username dan password yang dapat melakukan pemilihan.

b. Setiap orang yang telah melakukan pemilihan tidak dapat melakukan pemilihan lagi atau memperbaiki pilihannya

c. Pilihan dari pemilih dirahasiakan.

d. Pemilihan baru bisa dilakukan sesuai dengan jadwal yang telah ditentukan dan di akhiri juga sesuai dengan jadwal. e. Pemilih hanya dapat melakukan pemilihan saja.

Pada sistem ini pemilih akan mendapatkan undangan dan undangan tersebut akan ditukarkan dengan username dan password pada saat di TPS.

2. Analisis kebutuhan pengguna

Kebutuhan pengguna pada aplikasi e-voting ini adalah sebagai berikut :

a. Sistem dapat mengelolah data pemilih

b. Sistem dapat mengelolah data kandidat

c. Sistem dapat mengautentifikasi pemilih dalam melakukan pemilihan.

d. Sistem dapat melakukan proses pemilihan kepala desa.

e. Sistem dapat menambahkan jadwal pemilihan.

\subsection{Use Case}

Dari analisis kebutuhan yang telah didefinisikan terdapat user case yang diturunkan dari aktivitas kebutuhan tersebut sebagaimana berikut ini :

1. Sistem dapat mengelolah data pemilih
a. Tambah data pemilih
b. Mengubah data pemilih
c. Menghapus data pemilih
d. Melihat data pemilih
e. Mencetak undangan pemilih

2. Sistem dapat mengelolah data kandidat
a. Tambah data kandidat
b. Mengubah data kandidat
c. Menghapus data kandidat
d. Melihat data kandidat

3. Sistem dapat melakukan autentifikasi pemilih

a. Login Pemilih

4. Sistem dapat melakukan proses pemilihan
a. Melakukan proses pemilihan
b. Melakukan proses perhitungan suara.

5. Sistem dapat mengelolah jadwal pemilihan
a. Menambah jadwal pemilihan
b. Mengedit jadwal pemilihan
c. Menghapus data pemilihan
d. Mengaktifkan jadwal pemilihan
e. Mennonaktifkan jadwal pemilihan

\subsection{Class Diagram}

Diagram kelas adalah inti dari proses permodelan objek. Baik forward engineering maupun reverse engineering memanfaatkan diagram ini. Forward engineering adalah proses perubahan model menjadi kode program sedangkan reverse engineering sebaliknya merubah kode program menjadi model (Widodo dan Herlawati 2011). 


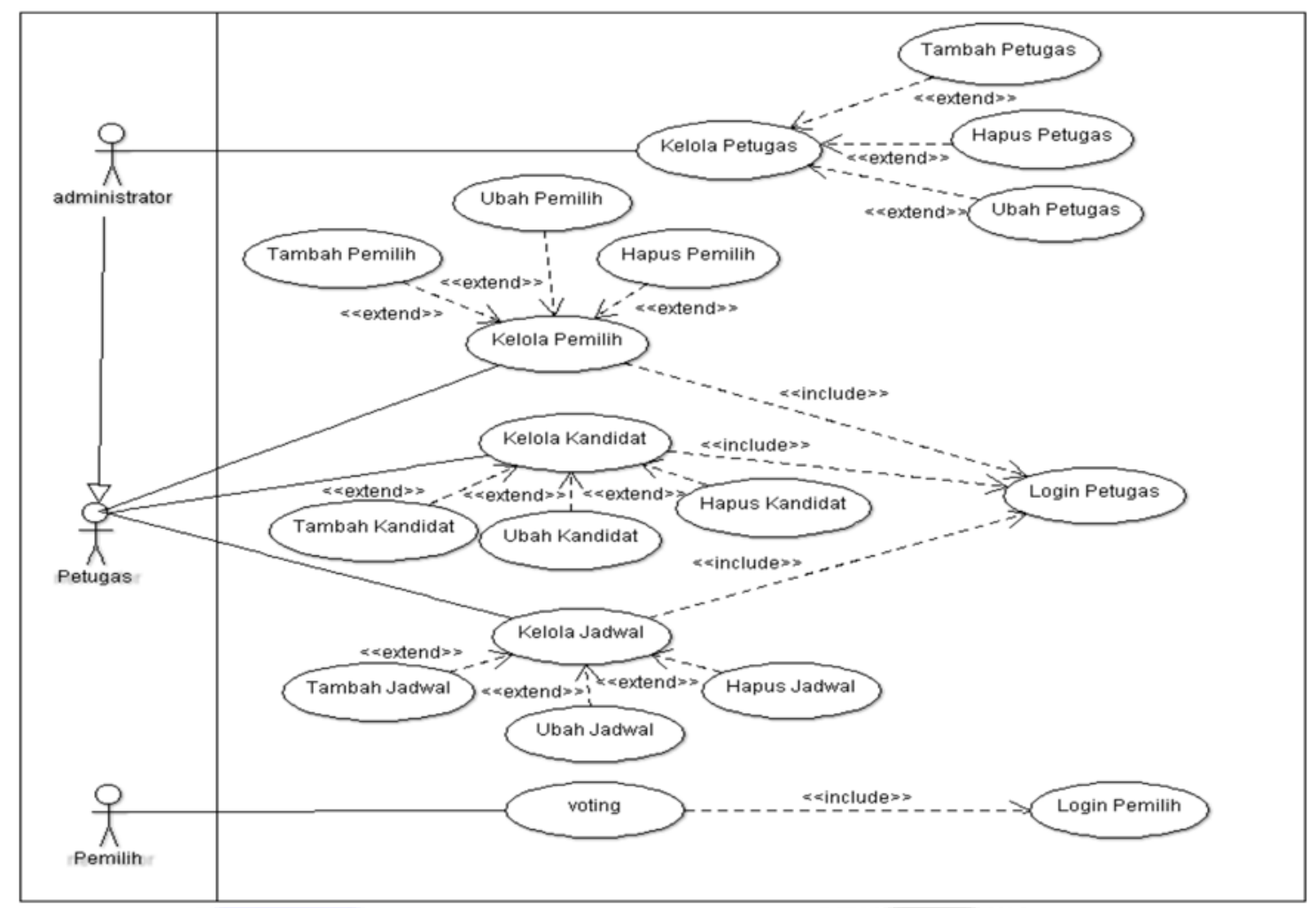

Gambar 3 Use Case E-Voting Pilkades Musi Rawas

\begin{tabular}{|l|}
\hline \multicolumn{1}{|c|}{ Pemilih } \\
\hline Id_pemilih* \\
username_pm \\
password_pm \\
nama_lengkap \\
nis \\
kelas \\
jenjang \\
jk \\
alamat \\
status \\
\hline + Simpan \\
+Batal \\
+Hapus \\
+Edit \\
\hline
\end{tabular}

\begin{tabular}{|l|}
\hline \multicolumn{1}{|c|}{ Petugas } \\
\hline $\begin{array}{l}\text { Usernamet * } \\
\text { Password } \\
\text { nama } \\
\text { hak_akses } \\
\text { status }\end{array}$ \\
\hline $\begin{array}{l}\text { + Simpan } \\
\text { +Batal } \\
\text { +Hapus } \\
\text { +Edit }\end{array}$ \\
\hline \multicolumn{1}{|c|}{ jadwal_pemilihan } \\
\hline $\begin{array}{l}\text { Id_jadwal* } \\
\text { tahun } \\
\text { tgl_mulai } \\
\text { status } \\
\text { aktif } \\
\text { username } * *\end{array}$ \\
\hline $\begin{array}{l}\text { + Simpan } \\
\text { +Hapus } \\
\text { +Edit }\end{array}$ \\
\hline
\end{tabular}

\begin{tabular}{|l|}
\hline \multicolumn{1}{|c|}{ Kandidat } \\
\hline Nis * \\
nama \\
kelas \\
foto \\
visi \\
\hline + Simpan \\
+Hapus \\
+Edit \\
\hline
\end{tabular}

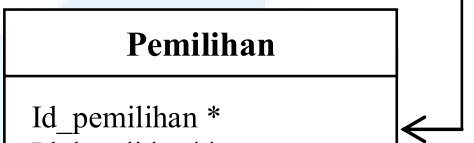

Id kandidat **

Id_jadwal **

+ Simpan

Gambar 4 Class Diagram

\subsection{Implementasi Sistem}

Dari hasil dan analisis yang telah di jelaskan sebelumnya maka dapat digambarkan rancangan antarmuka pengguna. Konsep desain antar muka di buat menjadi dua jenis yang dapat ditampilkan pada web browser pada PC dan browser untuk jenis WAP pada ponsel. Aplikasi e-voting ini akan dapat diakses ketika administrator mengklik tombol "aktif" sesuai dengan jadwal yang ditentukan baik tanggal maupun jam pelaksanaan.
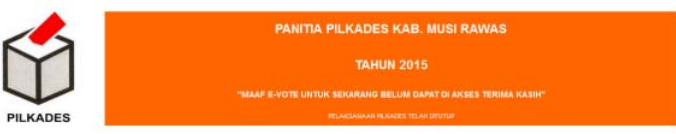

Gambar 5 Halaman Utama tidak aktif 


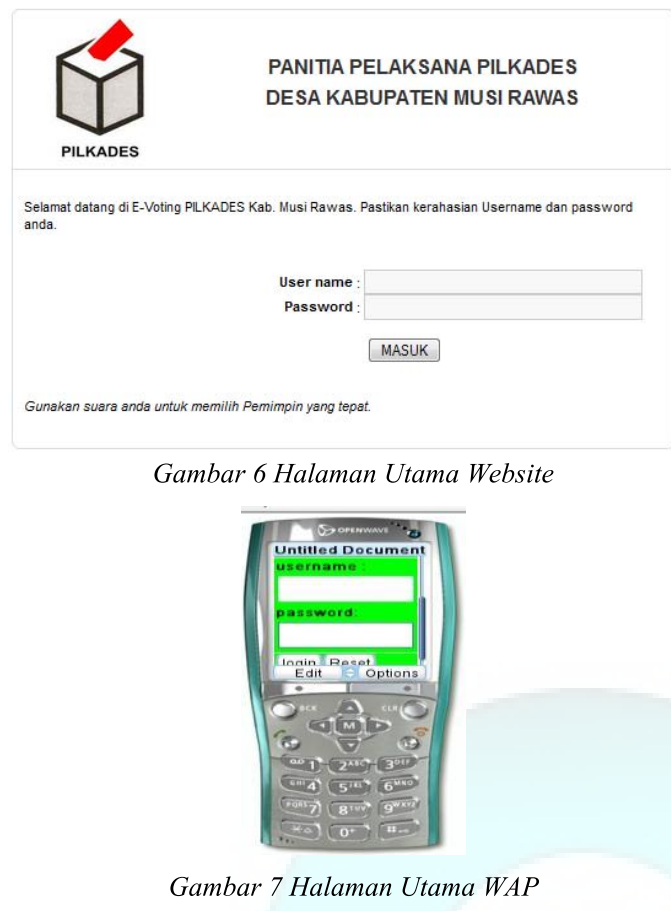

Gambar 5 menunjukan tampilan utama ketika aplikasi e-voting dalam keadaan tidak aktif. Gambar 6 merupakan tampilan halaman utama (login) dari aplikasi e-voting ini. Halaman utama disajikan dalam dua tampilan antar muka yaitu tampilan web dan WAP seperti yang terlihat pada gambar 7. Halaman utama ini berfungsi sebagai autentifikasi pemilih sebelum melakukan pemilihan. Username dan password didapatkan dari undangan yang diberikan oleh panitia pilkades. Gambar 8 menunjukan tampilan halaman administrator. Pada tampilan tersebut terdapat beberapa fungsi seperti dashboard, data master, laporan, users, dan pengaturan. Sebelum admin dapat mengakses halaman utama administrator, seorang admin memasukan username dan password untuk keamanan dari sistem. Penjelasan dari setiap komponen yang terdapat pada halaman antar muka administrator dideskripsikan pada tabel 1. Adapun tampilan yang digunakan untuk proses pemilihan ditunjukan pada gambar 9 dan 10. Proses pemilihan disajikan dalam bentuk dua format yaitu web dan wap. Halaman pemilihan disajikan dengan sederhana sehingga pemilih mudah dalam pengoperasiannya. Untuk tampilan pada browser WAP tidak ditampilkan foto calon kepala desa tetapi aplikasi hanya menampilkan nama dan nomor urut calon kepala desa yang ikut pemilihan.

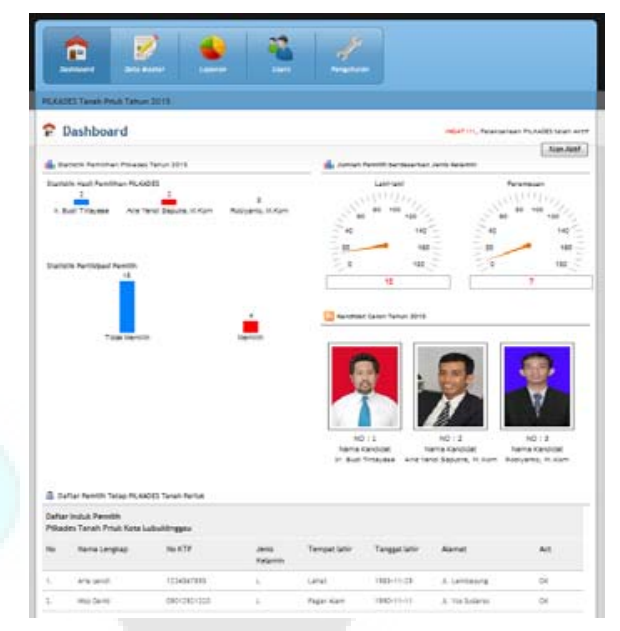

Gambar 8 Halaman Administrator

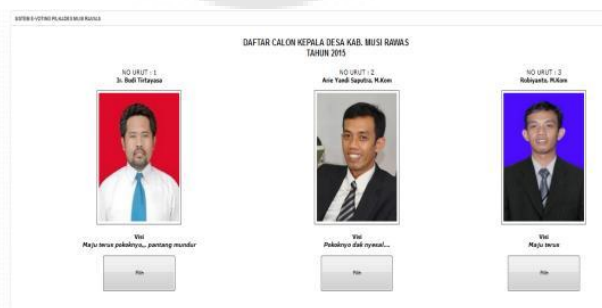

Gambar 9 Halaman Pemilihan Website

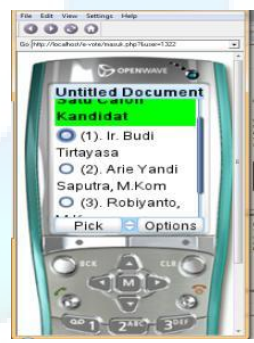

Gambar 10 Halaman Pemilihan WAP

BERITA ACARA PERHITUNGAN PEMUNGUTAN SUARA
PEMILIHAN KEPALA DESA TANAH PERIUK

HASIL PEMUNGUTAN SUARA

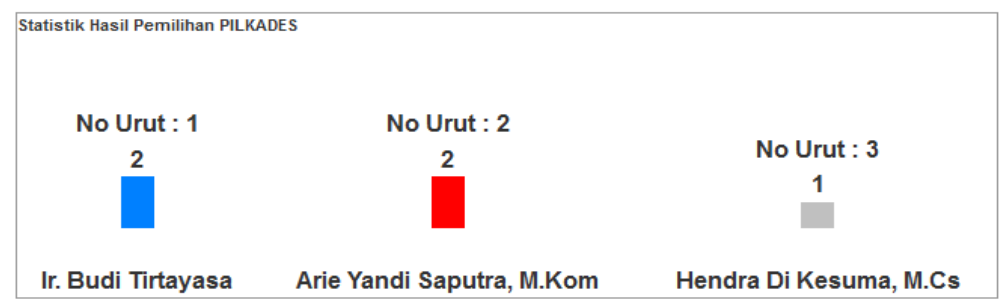

Gambar 11 Antarmuka Hasil Pemilihan 
Tabel 1. Deksripsi Halaman Utama Administrator

\begin{tabular}{|c|c|c|}
\hline $\begin{array}{l}\text { Komponen } \\
\text { antarmuka }\end{array}$ & Tujuan & Isi/Batasan/Tingkah Laku \\
\hline Dashboard & $\begin{array}{l}\text { Menunjukan informasi } \\
\text { perkembangan pelaksanaan } \\
\text { pemilihan kepala desa }\end{array}$ & $\begin{array}{l}\text { Informasi yang disajikan berupa hasil capaian suara, } \\
\text { gambar calon kepala desa, jumlah pemilih berdasarkan } \\
\text { jenis kelamin, dan data pemilih dalam bentuk tabular }\end{array}$ \\
\hline Data Master & $\begin{array}{l}\text { Menyajikan form input data } \\
\text { master }\end{array}$ & $\begin{array}{l}\text { Form input tersebut berupa form pemilih, form } \\
\text { kandidat, form jadwal pelaksanaan, dan form user. }\end{array}$ \\
\hline Laporan & $\begin{array}{l}\text { Menyajikan informasi hasil } \\
\text { pemilihan suara }\end{array}$ & $\begin{array}{l}\text { Menu laporan baru dapat diakses ketika pelaksaan } \\
\text { pemilihan selesai (admin menekan tombol nonaktif) } \\
\text { dalam menu ini terdapat fasilitas cetak hasil pemilihan. }\end{array}$ \\
\hline User & Mendata administrator & Berisikan form input data pengguna atau administrator \\
\hline Pengaturan & Mengelolah data master & $\begin{array}{l}\text { Berisikan informasi datamaster. Dalam komponen ini } \\
\text { administrator dapat melakukan perubahan data, dan } \\
\text { penghapusan data master. }\end{array}$ \\
\hline
\end{tabular}

Dalam pengoperasikan halaman pemilihan, pemilih tinggal mengklik tombol pilih pada calon kepala desa yang tersedia. Setelah pemilihan dilakukan maka username pemilih akan terblokir dan tidak dapat melakukan pemilihan lagi. Gambar 11 menunjukan tampilan berita acara hasil pemilihan. Menu ini merupakan hasil dari pelaksanaan pemilihan, dan dapat diakses jika pelaksanaan pemilihan telah dinyatakan habis atau form pemilihan telah di non aktifkan. Menu berita acara hasil pemilihan berfungsi sebagai pencetak hasil pelakasnaan pemilihan kepala desa. Informasi yang disajikan berupa grafik capaian hasil suara masing-masing calon, informasi total pemilih, informasi pemilih aktif (yang memilih), informasi pemilih yang tidak memilih.

\section{SIMPULAN DAN SARAN}

Berdasarkan hasil yang telah dicapai terkait tentang sistem pemilihan kepala desa dengan perangkat e-voting maka dapat disimpulkan bahwa:

1. Perangkat e-voting yang dibangun dapat diterapkan pada pemilihan kepala desa kabupaten Musi Rawas karena mengacu kepada aturan berdasarkan perda Nomor 4 Tahun 2013 dan standar keamanan e-voting, yaitu Eligibility, Unreusability, Anonymity, Accuracy, Fairness, Vote and Go, dan Public Verifiability.

2. Aplikasi $e$-voting dibangun tidak hanya mengatur pelaksanaan pemilihan dan perhitungan suara namun mengatur pendataan DPT. Sedangkan perangkat $e$-voting yang telah ada hanya melakukan pelaksanaan pemilihan dan perhitungan suara.

3. Pelaksanaan pemilihan kepala desa dapat dilakukan secara efektif dan efisien karna aplikasi ini dibangun dengan berbasiskan internet sehingga dapat dilakukan secara serentak.
Adapun saran pengembangan penelitian ini untuk selanjutnya adalah:

1. Aplikasi e-voting ini perlu dikembangkan untuk sinkronisasi data yang ada di catatan sipil yang berkaitan dengan DPT.

2. Teknologi keamanan pada aplikasi e-voting ini perlu ditingkatkan lagi.

\section{DAFTAR PUSTAKA}

Canard, S. dan Sibert, H., 2001. How to fit cryptographic e-voting into smart card. Perancis. IOS Press.

Fahmi, Husni i, Handoko, Dewi. 2010. Kajian Teknis tentang Pemungutan Suara secara Elektronik Teknologi Informasi dan Komunikasi, Badan Pengkajian dan Penerapan Teknologi, Jakarta.

Hajjar, M., 2006. An e-voting system for Lebanese elections. Journal of Theoretical and Applied Information Technology, pp. 21-22.

Hardjaloka, L., dan Simarmata, F., 2001. EVoting kebutuhan vs kesiapan (menyongsong) E-Demokrasi. Jurnal Konstitusi. Vol 8 Agustus 2011. Sekjen Kepaniteraan Mahkamah Konsitusi RI, Jakarta.

Isnaini, M., 2009. Analisis dan implementasi evoting sistem pada pemilihan kepala daerah. Departemen Ilmu Komputer IPB. Bogor

Mc. Leod, R., 2004. Management Information System. New Jersey: Pearson Education.

Perda Kab. Musi Rawas Nomor 4, Tahun 2013 Tentang tata cara pencalonan, pemilihan, pengangkatan, pelantikan dan pemberhentian kepala desa.

Rokhman, Ali. 2011. Prospek dan Tantangan Penerapan e-Voting di Indonesia. Seminar Nasional Peran Negara dan Masyarakat Dalam Pembangunan Demokrasi dan Masyarakat Madani di Indonesia, 7 Juli 2011. Universitas Terbuka, Jakarta. 